Lepr Rev (1986) 57, Supplement 3, 77-91

\title{
Experience with multidrug therapy in Sierra Leone: clinical, operational and managerial analysis
}

\author{
M RANGARAJ \& J RANGARAJ \\ National Leprosy Control Programme, Freetown, Sierra Leone
}

\section{Introduction}

MDT as recommended by WHO was introduced in March 1983. For the multibacillary cases the combination with clofazimine is used.

In January 1986, 1745 paucibacillary (PB) cases and 688 multibacillary (MB) cases were put on MDT. So far 1192 PB cases have been discharged after completing 6 months, MDT. None of the MB cases have been discharged yet.

Four hundred and forty-six PB cases who should have completed 6 to 33 months of follow up and $105 \mathrm{MB}$ cases who should have completed 12 to 33 months of treatment are analysed here. Of the 464 cases 124 were TT, 325 were BT, 14 were BB and 1 was I.

MDT was discontinued in $95(20 \cdot 4 \%)$ patients who failed to attend the clinics for 4 or more times. Three hundred and sixty-nine patients $(79 \cdot 6 \%)$ completed the full treatment within 6-9 months.

Looking through 15 years of annual reports of the Leprosy Control Programme, we found $28 \%$ of the known PB cases were recorded as out of control. In the remaining $72 \%$ of $\mathrm{PB}$ cases only 60 to $70 \%$ completed the full course of treatment (regular) before being discharged as cured.

From Table 5(a) and (b) it is seen that: The patients with single lesions tend to drop out more, compared to any other group. Presence of thickened nerve, deformity and ulcer makes the patients more regular. These two facts are also true with DDS monotherapy.

Table 6 shows that: $90 \%$ of the cases became inactive within a 6-month period. Many cases became inactive between 3 and 5 months. However $10 \%$ of the cases remained active at the end of a 6-month period. Similar monthly observation during the first 6 to 9 months of DDS monotherapy could not be found.

However, observation on a large number of PB cases at Dharmapuri, India ${ }^{1}$ gives the following data: Time taken for PB cases to become inactive: 1 , few skin 
Table 1. The status of the disease at commencement of MDT.

\begin{tabular}{lrccccc}
\hline & TT & BT & BB & I & Total \\
\hline Active & 33 & 113 & 3 & - & 149 \\
Inactive* & 91 & 212 & 11 & 1 & 315 \\
\hline Total & 124 & 325 & 14 & 1 & 464 \\
\hline
\end{tabular}

* Inactive cases who needed more than 12 months of DDS maintenance therapy were put on MDT.

Table 2. Break up according to number of skin lesions.

\begin{tabular}{|c|c|c|c|c|c|c|}
\hline & \multicolumn{4}{|c|}{ No. of patches } & \multirow{2}{*}{$\begin{array}{c}\text { No skin } \\
\text { lesion }\end{array}$} & \multirow[b]{2}{*}{ Total } \\
\hline & Single & 5 & $5-15$ & 15 & & \\
\hline Active & 38 & 38 & 57 & 16 & - & 149 \\
\hline Inactive & 79 & 95 & 98 & 32 & 11 & 315 \\
\hline Total & 117 & 133 & 155 & 48 & 11 & 464 \\
\hline
\end{tabular}

Table 3. The number of patients who had thickened nerve alone, thickened nerve + deformity and ulcers.

\begin{tabular}{lcccc}
\hline & $\begin{array}{c}\text { Thickened } \\
\text { nerve alone }\end{array}$ & $\begin{array}{c}\text { Thickened nerve } \\
\text { +ulcer }\end{array}$ & $\begin{array}{c}\text { Thickened nerve } \\
\text { +deformity }\end{array}$ & $\begin{array}{c}\text { Thickened nerve+ } \\
\text { deformity }+ \\
\text { ulcer }\end{array}$ \\
\hline Active & 14 & 3 & 17 & 3 \\
Inactive & 33 & 4 & 22 & 16 \\
\hline Total & 47 & 7 & 39 & 19 \\
\hline
\end{tabular}

lesions, 179 weeks; 2 , multiple skin lesions, 200 weeks; 3 , few and thickened nerve, 181 weeks; and 4, multiple and thickened nerve, 205 weeks.

It appears DDS monotherapy needs a much longer period of treatment to make an active case inactive, compared to MDT.

However in the absence of monthly follow ups during the first 6 to 9 months of treatment with DDS monotherapy, no definite conclusion could be drawn. 
Table 4. Attendance.

\begin{tabular}{lrrr}
\hline Treatment & Active & Inactive & \multicolumn{1}{c}{ Total } \\
\hline Discontinued & 35 & 60 & $95(20 \cdot 4 \%)$ \\
Completed in 6 months & 92 & 177 & $269(79 \cdot 6 \%)$ \\
Completed in 9 months & 22 & 78 & 100 \\
\hline Total & 149 & 315 & 464 \\
\hline
\end{tabular}

Table 5(a). Patients discontinued: relationship with number of patches.

\begin{tabular}{lllllll}
\hline $\begin{array}{c}\text { No. of } \\
\text { skin lesions }\end{array}$ & Single & 5 & 5 to 15 & 15 & $\begin{array}{c}\text { No skin } \\
\text { lesion }\end{array}$ & Total \\
\hline Active & 9 & 10 & 14 & 2 & - & 36 \\
Inactive & 29 & 8 & 24 & 2 & 2 & 60 \\
\hline Total & $34(29 \%)$ & $18(14 \%)$ & $38(25 \%)$ & $4(8 \%)$ & $2(18 \%)$ & $(20 \cdot 4 \%)$ \\
\hline
\end{tabular}

Table 5(b). Patients discontinued; relationship to thickened nerve, deformity and ulcer

Table 6. Time taken by the active cases to become inactive.

\begin{tabular}{|c|c|c|c|c|c|c|c|c|}
\hline Months & 1 & 2 & 3 & 4 & 5 & 6 & $\begin{array}{l}\text { Remained } \\
\text { active at } \\
6 \text { months }\end{array}$ & Total \\
\hline No. of cases & $\begin{array}{l}9 \\
8 \%\end{array}$ & $\begin{array}{l}14 \\
12 \%\end{array}$ & $\begin{array}{l}18 \\
16 \%\end{array}$ & $\begin{array}{l}17 \\
15 \%\end{array}$ & $\begin{array}{l}27 \\
24 \%\end{array}$ & $\begin{array}{l}17 \\
15 \%\end{array}$ & $\begin{array}{l}12 \\
10 \%\end{array}$ & 114 \\
\hline
\end{tabular}


Table 7(a).

\begin{tabular}{lrrrrrr}
\hline & Single & $<5$ & 5 to 15 & $>15$ & Total \\
\hline Became active at 6 months & 27 & 23 & 23 & 13 & 102 \\
Remained active at 6 months & 2 & 5 & 4 & 1 & 12 \\
\hline Total & 29 & 28 & 43 & 14 & 114 \\
\hline
\end{tabular}

Table 7(b).

\begin{tabular}{lcc}
\hline & $\begin{array}{c}\text { Thickened } \\
\text { nerve alone }\end{array}$ & $\begin{array}{c}\text { Thickened nerve+ } \\
\text { deformity }\end{array}$ \\
\hline Became inactive within 6 months & 14 & 18 \\
Remained active at 6 months & 3 & 2 \\
\hline
\end{tabular}

On further analysis it is found that there is no definite relationship between the number of patches and the time needed to make them inactive.

It appears that the involvement of nerve slightly prolongs the time duration; $13.5 \%$ of active cases with nerve involvement remained active at the end of 6 months treatment compared to $9 \cdot 1 \%$ of active cases without nerve involvement which remained active at the end of 6 months treatment.

\section{Follow up}

Altogether 14 out of 237 cases who came for follow up relapsed (relapse rate $5.9 \%$ ). The relapse rate among active cases is higher, $12 \cdot 3 \%$ compared to inactive cases $3.04 \%$. Out of 369 patients 132 never attend follow up clinics (dropout rate of $35 \%$ ). Varying relapse rates among PB cases have been reported with DDS monotherapy from $1.8 \%{ }^{1}$ to $15 \% .^{2}$ All the relapses have occurred within the first 18 months of follow up.

Eight out of 14 relapsed cases had 5 to 15 patches to start with. No definite relationship between the number of patches and number of relapse.

Active cases with nerve involvement relapsed more than the active cases without nerve involvement. The trend is opposite in inactive cases.

Percentage wise there is more relapse in BB followed by BT and very little in TT. There is no relationship between treatment irregularity and relapse, since all the relapsed cases completed their treatment in 6 continuous months.

No relapse has occurred in those patients who had typical atrophic, wrinkled, scarred lesions at the end of treatment. All the relapses have occurred in those who had residual, hypopigmented, vague lesions, but not actual scar and in those the skin lesions have totally disappeared. 
Table 8.

\begin{tabular}{lrrrr}
$\begin{array}{l}\text { Follow up } \\
\text { in months }\end{array}$ & Inactive & Relapse & Active & Relapse \\
\hline $\begin{array}{l}\text { Never came } \\
\text { for follow up }\end{array}$ & 91 & $?$ & 41 & $?$ \\
3 & 36 & 3 & 18 & 5 \\
6 & 25 & 2 & 9 & 2 \\
12 & 34 & Nil & 9 & 1 \\
18 & 34 & - & 13 & 1 \\
24 & 30 & - & 10 & \\
30 and above & 5 & - & 14 & \\
\hline Total & 255 & 5 & 114 & 9 \\
\hline
\end{tabular}

Table 9(a).

\begin{tabular}{cccccc}
\hline & Single & $<5$ & 5 to 15 & $>15$ & Total \\
\hline Active & - & 1 & 6 & 2 & 9 \\
& & $(3 \cdot 5 \%)$ & $(18 \cdot 1 \%)$ & $(14 \cdot 2 \%)$ & \\
Inactive & 3 & - & 2 & - & 5 \\
& $(5 \cdot 5 \%)$ & & $(2 \cdot 7 \%)$ & & \\
\hline Total & 3 & 1 & 8 & 2 & 14 \\
& $(3.6 \%)$ & $(0.86 \%)$ & $(7 \cdot 47 \%)$ & $(4 \cdot 5 \%)$ & \\
\hline
\end{tabular}

Table 9(b).

\begin{tabular}{lccc}
\hline & $\begin{array}{c}\text { With nerve } \\
\text { involvement }\end{array}$ & $\begin{array}{c}\text { Without nerve } \\
\text { involvement }\end{array}$ & Total \\
\hline Active & $\begin{array}{c}4 \\
(13 \cdot 3 \%) \\
1\end{array}$ & $\begin{array}{c}5 \\
(5 \cdot 9 \%) \\
4\end{array}$ & 9 \\
Inactive & $(1 \cdot 35 \%)$ & $(2 \cdot 2 \%)$ & 5 \\
\hline Total & $\begin{array}{c}5 \\
(4.8 \%)\end{array}$ & $\begin{array}{c}9 \\
(3 \cdot 3 \%)\end{array}$ & 14 \\
\hline
\end{tabular}


Table 10(c).

\begin{tabular}{cccccc}
\hline & TT & BT & BB & I & Total \\
\hline Active & - & 8 & 1 & - & 9 \\
& & $(9 \cdot 6 \%)$ & $(33 \cdot 3 \%)$ & & \\
Inactive & 1 & 4 & - & - & 5 \\
& $(1 \cdot 1 \%)$ & $(2 \cdot 5 \%)$ & & & \\
\hline Total & 1 & 12 & 1 & - & 14 \\
& $(0.8 \%)$ & $(5 \%)$ & $(7 \cdot 14 \%)$ & & \\
\hline
\end{tabular}

Table 11. The status of skin lesions at the end of treatment and the relapse.

\begin{tabular}{|c|c|c|c|c|c|c|}
\hline \multicolumn{2}{|c|}{ Scarred } & \multicolumn{2}{|c|}{ Residual } & \multicolumn{2}{|c|}{ Disappeared } & \multirow[b]{2}{*}{ Remained active } \\
\hline Total & Relapse & Total & Relapse & Total & Relapse & \\
\hline 65 & Nil & 222 & $\begin{array}{c}11 \\
(4 \cdot 9)\end{array}$ & 70 & $\begin{array}{c}3 \\
(4 \cdot 2 \%)\end{array}$ & 12 \\
\hline
\end{tabular}

The scarred lesions are probably the end result of high CMI reaching hypersensitive proportions. This is supported by the fact that Type I reaction treated with steroids invariably leaves a typical scar.

Whether the useful CMI and hypersensitivity are the same or not, whether one is associated with the other or not; it seems CMI bordering on to hypersensitivity level is needed for complete resolution of lesions and probably complete elimination of antigen.

Six out of the 14 cases that relapsed, relapsed with Type I reaction (42.8\%).

Type I Reaction occurred without, with and after stopping treatment, and occurred in both active as well as inactive cases. Further analysis showed that

Table 12. Relapse and Type I reaction.

\begin{tabular}{lccc}
\hline & Relapsed with & Relapsed with & Total \\
\hline Active & 2 & 7 & 9 \\
Inactive & 4 & 1 & 5 \\
\hline Total & 6 & 8 & 14 \\
& $(42 \cdot 8 \%)$ & $(57 \cdot 2 \%)$ & \\
\hline
\end{tabular}


Table 13. Type I reaction (eight patients with nine reactions).

\begin{tabular}{lcccc}
\hline & & & \multicolumn{2}{c}{ After stopping } \\
& Came with & During treatment & treatment & Total \\
\hline Active & 1 & 1 & 2 & 4 \\
Inactive & - & 1 & 4 & 5 \\
\hline Total & 1 & 2 & 6 & 9 \\
\hline
\end{tabular}

there is no relationship with the number of initial lesions. Nerve involvement, duration of treatment and regularity of treatment. Type I Reaction has been reported in those who never had treatment. ${ }^{3}$ It appears that the Type I reaction is a natural phenomenon in borderline leprosy to the dead bacterial antigen released to a threshold level. Antileprosy drugs caused release of dead antigen, one might expect a large number of Type I reactions with bacterioxidal drug rifampicin as compared to DDS monotherapy and in those who never had any antileprosy drugs. But this seems to be not true. It seems other factors like the amount, the type and the time of release of antigen and the immunological status of the patient at that time plays a major role in the production of Type I reaction.

Table 14(a). Follow up of cases who had Type I reaction.

\begin{tabular}{|c|c|c|c|c|}
\hline & Type & $\begin{array}{l}\text { Time of onset } \\
\text { of reaction }\end{array}$ & $\begin{array}{l}\text { Results af ter } \\
\text { treatment }\end{array}$ & Follow up \\
\hline \multirow[t]{4}{*}{ Active } & BT & 3rd month during MDT & Residual & $\begin{array}{l}\text { Relapsed } 16 \text { months } \\
\text { after with } \\
\text { active lesions }\end{array}$ \\
\hline & BT & $\begin{array}{l}\text { 2nd month during MDT } \\
11 \text { th month after stopping MDT }\end{array}$ & Still on steroids & $\begin{array}{l}\text { Following the } \\
\text { 2nd episode }\end{array}$ \\
\hline & BT & Came with Type I & Residual & 3 months O.K. \\
\hline & BT & 4th month during MDT & Scarred & $\begin{array}{l}\text { Never came for } \\
\text { follow up }\end{array}$ \\
\hline \multirow[t]{4}{*}{ Inactive } & BT & 3rd month during MDT & Scarred & 20 months O.K. \\
\hline & BT & $\begin{array}{l}\text { 2nd month after } \\
\text { stopping MDT }\end{array}$ & Scarred & 15 months O.K. \\
\hline & BT & $\begin{array}{l}\text { 3rd month after } \\
\text { stopping MDT }\end{array}$ & Scarred & 11 months O.K. \\
\hline & BT & $\begin{array}{l}9 \text { th month after } \\
\text { stopping MDT }\end{array}$ & Scarred & 3 months O.K. \\
\hline
\end{tabular}


All the Type I reactions were treated with steroids (low to moderate dose) for 3 to 6 months depending on clinical response. All responded well, 5 ending in scarred lesions, 2 with residual lesions. Follow up shows 2 relapsing 11 and 16 months after stopping steroids. One relapsed with Type I reaction and the other with active lesions.

\section{Follow up of relapsed cases}

Six out of 14 relapsed cases relapsed with Type I reaction, the follow up of these are given above. The follow up of the remaining 8 cases are given in Table 14(b).

No treatment was given to 5 patients, but they were observed monthly. Two became inactive, 7 and 3 months after relapse and remained inactive at 3 and 8 months follow up. Two are still active at 6 and 1 month after relapse. One patient relapsed with $\mathrm{BB}$, was found to have hepatic malignancy and died 2 months after. Three patients who remained active at the end of 6 months observation period were treated with low dose steroids on the assumption that the skin lesions are manifestation of DHS, even though there was no typical Type I reaction. Two

Table 14(b). Relapse: follow up.

\begin{tabular}{|c|c|c|c|c|}
\hline Type & $\begin{array}{c}\text { Relapsed } \\
\text { months after } \\
\text { stopping MDT }\end{array}$ & Treatment & Results & Follow up \\
\hline BT & 3 & $\begin{array}{l}\text { No treatment, } \\
\text { observation } \\
\text { only }\end{array}$ & Relapsed BB & $\begin{array}{l}\text { Died after } \\
2 \text { months } \\
\text { (hepatic malignancy) }\end{array}$ \\
\hline BT & 3 & & $\begin{array}{l}\text { IA residual } \\
7 \text { months }\end{array}$ & Month, 3 months O.K. \\
\hline BT & 3 & & $\begin{array}{l}\text { IA residual } \\
3 \text { months }\end{array}$ & 8 months O.K. \\
\hline BT & 4 & & $\begin{array}{l}\text { Still active at } 6 \text { months } \\
\text { observation }\end{array}$ & \\
\hline BT & 6 & & $\begin{array}{l}\text { Still active at } 1 \text { month } \\
\text { observation }\end{array}$ & \\
\hline BT & 6 & $\begin{array}{l}6 \text { months observation. } \\
\text { No improvement. } \\
\text { Steroids } \\
3 \text { to } 6 \text { months }\end{array}$ & IA scarred 3 months & 4 months O.K. \\
\hline BT & 4 & $"$ & $\begin{array}{l}\text { IA Residual } \\
6 \text { months }\end{array}$ & 3 months O.K. \\
\hline BT & 5 & $"$ & Still on steroids & 3rd month improving \\
\hline
\end{tabular}


responded well, one becoming inactive with scarred lesions and the other with residual lesion. The third is still on steroids and shows improvement at 3 months. It seems that all the cases relapsed with typical Type I reaction, and some of the cases relapsed with active lesions, are due to DHS. So these cases need not be considered as relapsed in the true sense. This means the relapse rate following 6 months MDT is not as high as many of us had feared.

Out of 12 cases which remained active at the end of MDT, 4 never came for follow up. The remaining 8 were observed without treatment. Four became inactive after 3, 4, 8 and 18 months of observation. One remained active at 24 months of observation (facial lesion). Three were put on low dose steroid when they were still active at the end of 6 months' observation. All the 3 became inactive in 3 months and remain inactive after 6,12 and 14 months of follow up.

\section{Side-effects of drugs used}

No side-effects noted. The change in the colour of the urine with rifampicin is actually welcomed by the patients, since many said that the drug was very effective because it can change the colour of urine, or that the disease is brought out through the urine.

In $\mathrm{PB}$ cases the MDT actually saves the cost. In MB cases the cost is enormous. It is seventeen times costlier compared with DDS monotherapy for one patient year. However by careful planning and gradual introduction of MDT among MB cases, it is possible that many programmes can introduce MDT without a very high increase in the regular yearly drug budget.

Table 15(c). Follow up of cases which remained active at the end of MDT.

\begin{tabular}{|c|c|c|c|c|}
\hline Type & Treatment given & Results & & Follow up \\
\hline BT & $\begin{array}{l}\text { No treatment, observation } \\
\text { only }\end{array}$ & IA residual & 8 months & 14 months O.K. \\
\hline BT & 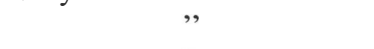 & IA residual & 18 months & 6 months O.K. \\
\hline BT & " & IA residual & 3 months & 12 months O.K. \\
\hline BT & $"$ & IA scarred & 4 months & 3 months O.K. \\
\hline BT & $"$ & $\begin{array}{l}\text { Still active at } \\
\text { (f acial lesion) }\end{array}$ & & 24 months \\
\hline BT & $\begin{array}{l}\text { Observation } 6 \text { months. No } \\
\text { improvement. } \\
\text { Steroid } 3 \text { to } 6 \text { months }\end{array}$ & IA Residual & & 12 months O.K. \\
\hline BT & $"$ & IA Scarred & & 14 months O.K. \\
\hline BT & $"$ & IA Scarred & & 6 months O.K. \\
\hline
\end{tabular}


Table 16. The cost of drugs and patient years saved.

\begin{tabular}{lcr}
\hline & Patient years saved & Cost saved \\
\hline Active & 3.42 & $13.06 \mathrm{DM}$ \\
Inactive & 1.72 & $6.57 \mathrm{DM}$ \\
\hline Total & 2.24 & $8.55 \mathrm{DM}$ \\
\hline
\end{tabular}

Cost of 1 year's DDS-3.82 DM. Cost of 6 months' MDT for PB cases8.38 DM. Cost of one year's MDT for MB cases-65.4 DM.

\section{Workload and caseload}

A reduction in the caseload is dramatic, especially in the first two years.

Despite the fall in the caseload the workload remains the same (or) actually increases.

\section{Difficulties faced}

The Medical Officer or other responsible person has to visit all the MDT cases once a month to see that the drugs are actually reaching the patient and in order to avoid misuse and abuse of the drugs.

This task is made much more difficult by difficult road conditions, a large area to be covered, 6 months rain, non-availability of petrol, and worsening economic conditions.

\section{Conclusions}

1 It seems the course of events in PB cases are mainly determined by the individual's immunological status rather than a particular antileprosy drug or their combination.

2 In the presence of useful immunity in PB cases, the main advantage of MDT over DDS monotherapy seems to be the reduction in the duration of treatment.

3 The fear of large number of relapses following 6 months' MDT seems unjustified.

4 In a situation like ours where only $43 \cdot 2 \%$ of PB cases complete their full treatment and these patients were seen and assessed by the Medical Officer only 
once in a year, introduction of MDT has reversed the whole situation in that $80 \%$ complete the full course of treatment. All the patients could be seen and assessed every month, with a good $65 \%$ follow up.

5 Short-term MDT seems to be the best solution for PB cases in our set up.

\section{Multibacillary cases}

Total number of cases analysed, 105; deletions (died, transferred etc.), 8; remaining on treatment, 97 ; regular ( $75 \%$ attendance), 87 (89.7\%); irregular, 10 $(10 \cdot 3 \%)$.

The overall attendance rate among $\mathrm{BL}$ and $\mathrm{LL}$ cases are always higher compared with PB cases since the beginning of the Programme in 1973. However we never once reached $89.7 \%$ regular attendance in MB cases. In fact many defaulters and out of control patients whom we could not trace before are returning for treatment, once they have heard about the new drugs.

\section{7 cases (33 BL, 54 LL) who are regular are analysed further}

Table 17.

BL LL Total

\begin{tabular}{llll}
\hline Active (BACT + VE) & 16 & 30 & 46 \\
Inactive (BACT - VE) & 17 & 24 & 41 \\
\hline Total & 33 & 54 & 87 \\
\hline
\end{tabular}

The 41 inactive cases were put on MDT for the following reasons: 1, They were bacteriologically positive within the last 12 months before MDT started. 2, Most of them needed 10-15 years of DDS maintenance therapy. 3, In the bush clinics, if one patient gets DDS alone and another is given special drugs, it will be considered discriminatory, which might lead to irregularity among DDS monotherapy patients.

\section{Clinical Observation}

INACTIVE CASES

As one expected, nothing much is observed in the clinical picture of inactive cases except reactions and other complications which are dealt with later. 
Table 18.

\begin{tabular}{lcccc}
\hline $\begin{array}{l}\text { Clinical } \\
\text { improvement }\end{array}$ & Very good & Good & $\begin{array}{c}\text { No or very } \\
\text { little improvement }\end{array}$ & Total \\
\hline BL & $\begin{array}{c}5 \\
(31 \cdot 2 \%) \\
4\end{array}$ & $\begin{array}{c}11 \\
(68 \cdot 8 \%) \\
26\end{array}$ & Nil & 16 \\
LL & $(13 \cdot 3 \%)$ & Nil & 30 \\
\hline Total & 9 & 37 & & \\
\hline
\end{tabular}

\section{ACTIVE CASES}

The clinical improvement is graded as: 1, Very good, notable change in the clinical picture within 3 months of MDT. 2, Good, notable change within 6 months of MDT. 3, No improvement, no change at 6 months of MDT.

Table 18 shows that: Percentage wise the improvement is quicker compared to LL (as is true with DDS monotherapy). Comparison of initial BI with clinical improvement showed no definite relationship, in fact the higher the initial BI and more active is the initial infiltration, the more dramatic is the change in clinical picture.

The overall impression is that the clinical improvement is dramatic and quick

Table 19. Twelve (6 BL, $6 \mathrm{LL})$ out of 46 active cases became bacteriologically negative.

\begin{tabular}{|c|c|c|}
\hline Type & Initial BI & $\begin{array}{c}\text { No. of months after MDT } \\
\text { became negative }\end{array}$ \\
\hline $1 \mathrm{BL}$ & 1 & 6 \\
\hline $2 \mathrm{BL}$ & 1 & 10 \\
\hline $3 \mathrm{BL}$ & 2 & 11 \\
\hline $4 \mathrm{BL}$ & $2 \cdot 6$ & 30 \\
\hline $5 \mathrm{BL}$ & $3 \cdot 0$ & 17 \\
\hline $6 \mathrm{BL}$ & $3 \cdot 5$ & 31 \\
\hline $7 \mathrm{LL}$ & 1 & 16 \\
\hline $8 \mathrm{LL}$ & $1 \cdot 0$ & 9 \\
\hline $9 \mathrm{LL}$ & $1 \cdot 3$ & 19 \\
\hline $10 \mathrm{LL}$ & $1 \cdot 3$ & 9 \\
\hline $11 \mathrm{LL}$ & $1 \cdot 5$ & 15 \\
\hline $12 \mathrm{LL}$ & $2 \cdot 0$ & 24 \\
\hline
\end{tabular}

Average fall in BI in BL cases: $1 \cdot 46 /$ year.

Average fall in LL cases: 1 /year. 
with MDT compared to DDS monotherapy but this may be due to the fact that we are observing these patients closely and keenly every month (which we were not doing with DDS monotherapy patients).

\section{Bacteriological observation}

There is no relationship between the initial $\mathrm{BI}$ and the number of months of MDT needed to make them negative. Fall in BI is quicker in BL $(1.46 /$ year $)$ compared to LL (1/year). Analysis of the remaining 34 cases (10 BL, $24 \mathrm{LL}$ ) still bacteriologically positive showed that: there is no definite pattern in the fall of BI either in BL or LL; no relationship between the initial BI and the rate of fall in the $\mathrm{BI}$; and MDT seems to have little or no action on the clearance of bacteria as with DDS monotherapy.

\section{Reactions: Type I reaction}

Two active cases with the initial BI of 3.4 and 3.3 developed typical Type I reaction and both responded well to steroids. Two inactive cases developed red, well- and ill-defined lesions with very little loss of sensation. These could be called immunological upgrading rather than reaction. Both responded well to continuing MDT.

Table 20. (Four patients, six reactions.)

\begin{tabular}{clc}
\hline Type & $\begin{array}{c}\text { Month } \\
\text { after MDT started }\end{array}$ & Severity \\
\hline Active & & \\
BL & $3,11,26$ & Moderate \\
LL & 2 & Moderate \\
Inactive & & \\
BL & 11 & Mild \\
LL & 14 & Mild \\
\hline
\end{tabular}

\section{ENL}

Eight out of 87 patients developed erythema nodosum leprosum (rate $9 \cdot 2 \%$ ), only two had severe ENL. Varying rates of ENL following MDT has been reported. ENL developing in $42 \cdot 6 \%$ of the patients following MDT has been 
Table 21. (Eight patients, ten reactions.)

\begin{tabular}{lcl}
\hline \multicolumn{1}{c}{ Months after } & \\
Type & MDT started & Severity \\
\hline Known, repeated ENL patients & & \\
LL & 9 & Mild \\
LL & 17 & Mild \\
LL & 9 & Mild \\
LL & 1,6 & Mild \\
Never had ENL bef ore & & \\
BL & 4 & Mild \\
LL & 14 & Mild \\
LL & 23,26 & Severe \\
LL & 9 & Severe \\
& & \\
\hline
\end{tabular}

reported. ${ }^{4}$ The low incidence of ENL in our series seems to be due to the clofazimine we use in our combination. Relief from ENL in repeated ENL patients has restored their confidence in treatment and regularity and also reduced the admissions at the hospital due to ENL.

\section{Drugs-side-effects}

No side-effect to DDS or rifampicin were noted. Regarding clofazimine there is a clear change in the colour of the skin. However it is not so obvious as in a fair skinned person.

All the patients accepted becoming a little darker, as long as they could see good clinical improvement and the hope of stopping treatment after some years. Dryness of the skin and conjunctiva was seen in $41 \cdot 1 \%$ and $2 \cdot 2 \%$ of the cases respectively. Strangely, none of them complained about it.

On the day they had to swallow 2 rifampicin +3 clofazimine +1 DDS together a few patients complained of vague abdominal discomfort.

\section{Conclusions}

1 Early and dramatic clinical improvement is seen.

2 Bacteriological status does not show such improvement.

3 Reduction in the number and severity of ENL attacks, especially in repeated ENL cases.

4 Improvement in our attendance rate to $90 \%$.

5 Drugs are well tolerated and accepted by our patients. 
6 We are at a stage when we should start stopping treatment in many cases. However, the uncertainty we had at the beginning of MDT regarding theraputic end-point and the criteria for theraputic end-point still remains.

7 This uncertainty is made worse by the known facts that none of the antileprosy drugs concerned have any significant action on dormant bacilli.

8 In the absence of useful immunity in MB cases, the main use of MDT seems to be the prevention of drug resistance.

\section{References}

Ekambaram V. Duration of treatment for disease arrest in non-lepromatous cases and relapse rate in these patients. Lepr Rev, 1979, 50, 297-302.

2 Touw-Langendijk EMJ, Naafs B. Relapse in leprosy after release from control. Lepr Rev. 1979; 50, 123-7.

${ }^{3}$ Naafs B, Wheate HW. The time interval between the start of antileprosy treatment and the development of reactions in borderline patients. Lepr Rev, 1978; 49, 153-7.

${ }^{4}$ Jopling W H et al. A follow up investigation of Malta project. Lepr Rev, 1984; 55, 247-53. 